\title{
EFFECT OF ERRQ STRATEGY FROM TEXT TYPES BY EIGHTHGRADE STUDENTS' READING COMPETENCY
}

\author{
By \\ Luh Widiani \\ Sekolah Tinggi Pariwisata Mataram \\ Email: iluhwidhi29@gmail.com
}

\begin{abstract}
The problems were focused on the following, they are: 1) the main effect of scientific approach combined with ERRQ strategy on the eighth graders' reading competency, 2) the differences of the effect of scientific approach combined with ERRQ strategy viewed from text types on the eighth graders students' reading competency. The research methods were the following. The population included students at SMP Santo Yoseph Denpasar. The sample were recruited from the eighth grade of SMP Santo Yoseph Denpasar. They were recruited using a Random Sampling. Data were collected by means a Posttest. The obtained data were analyzed by means of One-Way ANOVA. The results show the following: 1 ) there is a significant effect of scientific approach combined with ERRQ strategy on the students' reading competency which total mean score (X: 77.27) ( $\lambda$ : 0.01); 2) The differences of the effect of scientific approach combined with ERRQ strategy viewed from text types on the students' reading competency could be arranged consecutively as follows: narrative text (X:76.47), recount text (X:78.78), descriptive text (X: 76.83).

Keywords: Reading Competency, ERRQ Strategy \& Text Types
\end{abstract}

\section{PENDAHULUAN}

Indonesia has been changing the curriculum several times. Curriculum is actually made based on social condition occurring in environment related with moral value that has to be changed. Because of it, the government made curriculum 2013 (Kemdikbud, 2013). Every school needs a curriculum as guidance for running the education process; the curriculum which is formally implemented in the context of the present study is curriculum 2013. New policy in education has been made by Indonesian Goverment that Curriculum 2013 is implemented in all levels of education in Indonesia. This curriculum is the refinement of the previous curriculum called Kurikulum Tingkat Satuan Pendidikan (KTSP). According to the document of Curriculum 2013 published by the ministry of education and culture of Indonesia, it is stated that there are several weaknesses found in KTSP; curriculum content is still too dense which is indicated by the number of lesson and a lot of materials that go beyond the scope and level of distressing the level of development of the child's age; the describe attitudes, skills, and knowledge. It puts the domain of knowledge as the main aspect in teaching and learning process while skills and attittudes are given less attention since skill and attitudes are not inserted in every subject. Moreover, the process of teaching and learning in the classroom tends to use teacher-centered rather than student-centered approach (Kemdikbud, 2013).

Regarding the above weaknesses, KTSP 2006 then has been developed into curriculum 2013. There are three elements of the curriculum with have been refined. The first element is about graduate standard competency (SKL). Curriculum 2013 emphasizes on the balance of soft skills and hard skills by putting attitude, knowledge, skill, and character education as the main aspect in education, in which the learners are expected to comprehend the material, to be activefly involved in discussion, presentation, and have high selfdiscipline and politeness. By implementing Curriculum 2013, a teacher as a school community member can help to overcome 
moral degradation of the young generation. The second element is about the topics with are relevant to the competency being highlighted. It means that the number of topics learned by the students is presented integratedly and based on the competency that they have to master as stated in the graduate standard competency (SKL). The last refined element in Curriculum 2013 is about the teaching approach. It means that in teaching and learning process is designed to apply scientific approach.

In this study focused in reading competency. For one year learning process by using the Curriculum 2013, reading competency is still not successful because many students got low scores in reading so it is not achieve mastery. Lack of students in reading due lots of student get problem in making meaning from what they read and cannot comprehend the content of the text.

Learning reading has been developed for a long period of time and many researchers had done research to investigate the appropriate reading strategies to help students enhancing their understanding, the students are still struggling to comprehend the reading text. It matched with the facts that the researcher found as the result of pre-observation in SMP Santo Yoseph Denpasar, in teaching reading, the English teacher asked the students to observed and read the text in the book given by teacher, underline the difficult words and find that words in the dictionary, then, teacher ask questions and ask the students to collected information about text next to associated what the text about by made group then, communicated the result that have associated. But most of students looked confused and disinterested because the steps used make the students difficult to understand the texts. This scientific approach may make the students difficult to remember about what they have learned and the students may not feel interested and motivated to develop their reading competency.

Teachers need to use a more systematic strategy in teaching as stated by Robinson (cited in Bayu, 2008) that method of teaching reading is considered an important factor affects a comprehension in reading. Winch (2006) stated that the systematic teaching of reading sub skill is important in each level of the early school years. Furthermore, Brown (2001) stated that subdivide teaching technique into pre-reading, during reading and after reading phase. Pre-reading prepares students for learning by activating their prior knowledge about the topic featured in the text. Spend some time introducing a topic, encouraging skimming, scanning, predicting, activating schemata. During reading strategies teach comprehension by making connection, generating, questions, and determining importance by guiding the reader to use proficient reader strategies. After activities connect the old and new knowledge and help students frame it in some way to their lives. This stage is use to follow up and confirm what was learned (e.g answer question or confirm predictions from the use of before and during reading phase).

\section{THEORETICAL REVIEW The Curriculum 2013}

According to the Constitution No.20 (2003) about The National Education System, curriculum is a set of planning and regulation covering the purposes, content, and learning material as well as strategies to be used as a guide line to manage instructional activities to achieve particular educational goal.

Curriculum 2013 is a learning competency through strengthen the learning process and authentic assessment to achieve attitude competency, knowledge, and skill. Strengthen of learning process given by scientific approach is to encourage the students' process of learning by observing, questioning, experimenting, associating, communicating.

Learning principal used in the Curriculum 2013 emphasizes on paradigm alteration: the student looking for the material, the teacher as the resource to learn, textual approach becomes a process to use scientific approach, content based learning becomes competency based, particle learning becomes integrated learning, the answer emphasizing on singular becomes the dimension, verbal 
learning becomes applicative skill, improvement between hard skill and soft skill, learning focus on student's culture, applied learning using values of providing model, willing to develop, and developing students creativity in learning process, learning process applied in school, house, and society, learning process applied all people is teacher, all people is student, and whatever is classroom. Information of technology and communication will be used to improve learning efficiency and effectiveness.

\section{Reading Competency}

According to Grabe \& Stoller (2002), reading competency is mastering the ideas and contents of reading passage through analyzing, evaluating and combining the idea with their prior knowledge. The students who have good reading comprehension, are those who have ability to answer questions of the text (cognitive competency), to create questions and dramatizing the text (affective competency, and summarize the text (psychomotor competency). The competency means that related with competency based langauge teaching is the "task based syllabus". The syllabus is organized around tasks that students complete in the target language. The basic principle is that students can acquire necessary skills when they are learning. The material in the syllabus considerate the genre based materials in addition to its authenticity and level of difficulty.

To help students achieve the competency in reading, the teachers should apply approaches, methods, strategy and teaching techniques which suit the characteristics of the students and the capacity and resources available in the school. The skill and strategy must be appropriate to the type of the text and to the understanding of how to apply them to accomplish the reading purpose; this will be measured by administering reading competency test.

\section{Scientific Approach}

Scientific approach must be effective in order to increase students' learning outcomes. This approach is also considered relevant with the idea that learning is a scientific process in the classroom. It produces of three domains, namely: attitude, knowledge, and skill. In scientific based learning, the attitude domain leads the students "know why". The domain of skill leads the students "know how" meanwhile knowledge domain leads the students "know what". These three domains are expected to make students affective, creative, innovative, and productive. In short, with these three domains, the students can get soft skills to live as well. In order to reach these goals in the implementation of this approach, the teachers do the five steps in teaching and learning process. They are observing, questioning, associating, experimenting, and networking. Kemdikbud (2013),

\section{ERRQ Strategy}

ERRQ Strategy is a strategy reading that help the students to understanding meaning from the text. The four letters in the acronym of ERRQ strategy is stand for Estimate, Read, Respond, and Question. It supported by Schweihofer and Wassman (2003) ERRQ is a strategy that involves students' questioning of text to gain meaning and allows for students to decide how far they can read with understanding and then read that portion. They respond the information by reacting it and forming a question about it. This strategy will involve a variety of text choices.

Moreover, Smith et.al (2012) stated ERRQ is estimate how much of the reading assignment you can read, at one sitting, and understands. Read the passage. Respond to the information in the passage in writing. Be sure to include a brief summary as well as your thoughtfully written response. Write two or three questions based on the information contained in your response. So to comprehend the text, the students should estimate how far they can read, after read they give respond and question by written.

\section{Procedures of ERRQ Strategy}

In teaching reading competency using ERRQ strategy is a reading strategy that involves students' questioning of text to gain meaning. The procedures of ERRQ strategy (estimate, read, respond, and question as stated by Anchin and Iswara (2013): 
1. Estimate. Students look over the text and estimate how far they can read and maintain understanding. They identify the text portions with a light pencil mark.

2. Read. Students read the text silently, orally, or with a partner in paired reading. They are urged to consider how the text affects them. What images come to mind as they read? Does the text remind them of anything from their experience?

3. Respond. After reading, students react. What comes to mind as they read? What images or feelings are evoked? If students are working with partners, they share oral and retell with their partners. If students are working individually, they retell everything they can remember to themselves or write their responses down for future reference.

4. Question. Students generate questions about the reading. If students have marked the text by paragraphs or smaller portions of text, they may create questions about each of the marked portions, or they may ask general questions about the whole pieces. The teacher may collect the questions for evaluation purposes.

Based on the procedures that were written by resources above, the writer adapts these procedures into her own teaching procedures to meet the characteristic of students in Indonesia. The steps of ERRQ strategy are as follows:

1. The teacher chooses and distributes the text types (narrative, recount, descriptive) and demonstrates the process.

2. The teacher asks students to look over the text and estimate how far they can read the text and maintain understanding

3. The teacher asks students to read the text silently, orally, or with a partner in paired reading

4. Respond. After reading, the teacher asks students to work with partners, they share oral and retell with their partner

5. The teacher asks Students to generate questions about the reading

6. The teacher collects the questions from the students for evaluation purposes

\section{Text Types}

Texts are divided into several types based on generic structure and language feature dominantly used (Erawati, 2012). Furthermore Richards and Schmidt (2002) state that genre has distinctive and recognizable patterns and norms of organization and structure, and that has particular and distinctive communicative function. For example: narrative, recount, descriptive, report, explanation, analytical exposition, hortatory exposition, procedure, discussion, review, anecdote, spoof and news item. Based on the curriculum 2013, there are three types of text taught to eighth grade students of junior high school in second semester. Thoe texts are narrative, recount, and descriptive.

Comparison of Scientific Approach Combined with ERRQ Strategy and Scientific Approach without ERRQ Strategy (Conventional Strategy)

The process of using scientific approach combined with ERRQ strategy and scientific approach without ERRQ strategy are carried out through step by step procedures in three stages of reading process: before-reading, during-reading, and after-reading activity. In order to make the difference between the two strategies clear, the comparison of the two strategies is presented in the table 2.1.

Table 1. Table of Comparison of Scientific Approach Combined with ERRQ Strategy and Scientific Approach without ERRQ Strategy

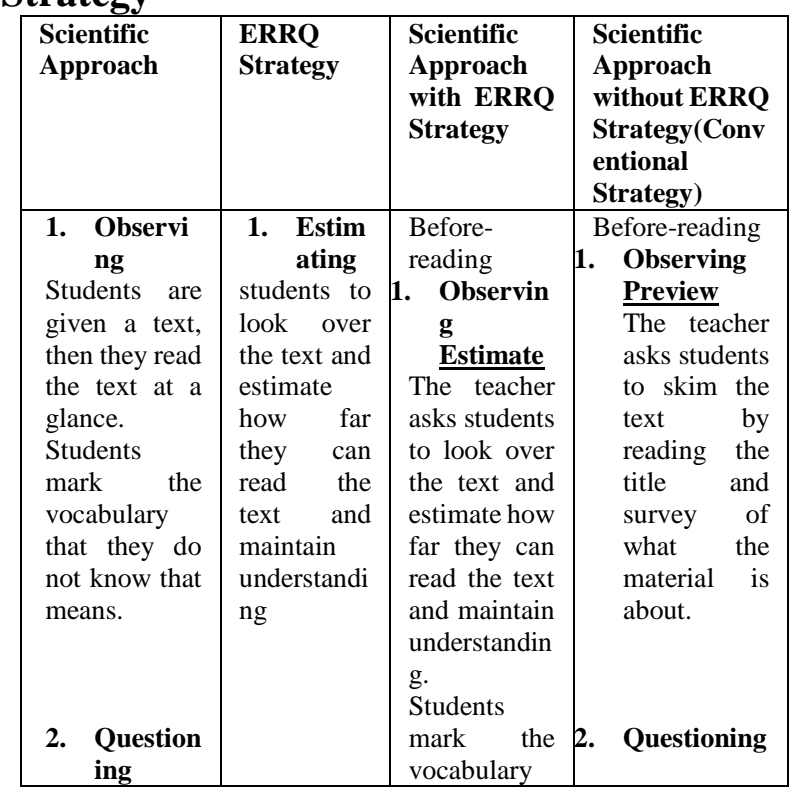




\begin{tabular}{|c|c|c|c|}
\hline $\begin{array}{l}\text { Students } \\
\text { questioned the } \\
\text { difficult } \\
\text { vocabulary } \\
\text { found in text. } \\
\text { Teacher give } \\
\text { the answer of } \\
\text { questions } \\
\text { students }\end{array}$ & & $\begin{array}{l}\text { that they do } \\
\text { not know } \\
\text { that means. } \\
\text { 2. Questioni } \\
\text { ng } \\
\text { The teacher } \\
\text { asks students } \\
\text { to ask } \\
\text { questions } \\
\text { about the } \\
\text { information } \\
\text { that is not } \\
\text { understood } \\
\text { from what is } \\
\text { observed. } \\
\text { Teacher give } \\
\text { the answer } \\
\text { of questions } \\
\text { students }\end{array}$ & $\begin{array}{l}\text { The teacher asks } \\
\text { students to ask } \\
\text { questions about } \\
\text { the information } \\
\text { that is not } \\
\text { understood from } \\
\text { what is observed. }\end{array}$ \\
\hline $\begin{array}{l}\text { 3. Collectin } \\
\text { g } \\
\text { Informa } \\
\text { tion } \\
\text { Students } \\
\text { determine the } \\
\text { generic } \\
\text { structure of } \\
\text { text, identify } \\
\text { the main idea } \\
\text { of paragraph, } \\
\text { match the } \\
\text { words of text } \\
\text { with synonym } \\
\text { and answer } \\
\text { the question } \\
\text { that given in } \\
\text { text. }\end{array}$ & $\begin{array}{l}\text { 2. Readi } \\
\quad \text { ng } \\
\text { Students to } \\
\text { read the } \\
\text { text } \\
\text { silently, } \\
\text { orally }\end{array}$ & $\begin{array}{l}\text { During- } \\
\text { reading } \\
\text { 3. Collectin } \\
\text { g } \\
\text { Informat } \\
\text { ion } \\
\text { Read } \\
\text { The teacher } \\
\text { asks students } \\
\text { to read the } \\
\text { text silently, } \\
\text { orally, or } \\
\text { with a } \\
\text { partner in } \\
\text { paired } \\
\text { reading. } \\
\text { Students } \\
\text { determine } \\
\text { the generic } \\
\text { structure of } \\
\text { text, identify } \\
\text { the main } \\
\text { idea of } \\
\text { paragraph, } \\
\text { match the } \\
\text { words of text } \\
\text { with } \\
\text { synonym and answer } \\
\text { and } \\
\text { the question } \\
\text { that given in } \\
\text { text. }\end{array}$ & $\begin{array}{l}\text { During-reading } \\
\text { 3. Collecting } \\
\text { Information } \\
\text { Categorize } \\
\text { Theacher } \\
\text { asks students } \\
\text { to read and } \\
\text { then find the } \\
\text { information } \\
\text { that is related } \\
\text { pieces are on } \\
\text { the text or } \\
\text { category }\end{array}$ \\
\hline $\begin{array}{l}\text { 4. Associati } \\
\text { ng } \\
\text { Students } \\
\text { discuss } \\
\text { appropriate } \\
\text { solutions to } \\
\text { the problems } \\
\text { that occur in } \\
\text { text with } \\
\text { group. }\end{array}$ & $\begin{array}{l}\text { 3. Respo } \\
\text { nding } \\
\text { Students to } \\
\text { work with } \\
\text { partners, } \\
\text { they share } \\
\text { oral and } \\
\text { retell with } \\
\text { their } \\
\text { partner } \\
\text { about what } \\
\text { they } \\
\text { already } \\
\text { know about } \\
\text { a text }\end{array}$ & $\begin{array}{l}\text { After- } \\
\text { reading } \\
\text { 4. Associati } \\
\text { ng } \\
\text { Respon } \\
\text { After } \\
\text { reading, the } \\
\text { teacher asks } \\
\text { students to } \\
\text { work with } \\
\text { partners, } \\
\text { they share } \\
\text { oral and } \\
\text { retell with } \\
\text { their partner } \\
\text { about what } \\
\text { they already } \\
\text { know about } \\
\text { a text. } \\
\text { Students }\end{array}$ & $\begin{array}{l}\text { After-reading } \\
\text { 4. Associating } \\
\underline{\text { Group }} \\
\underline{\text { Work }} \\
\text { Teacher leads } \\
\text { students to } \\
\text { make a group to } \\
\text { share their } \\
\text { ideas with each } \\
\text { member. }\end{array}$ \\
\hline $\begin{array}{l}\text { Students } \\
\text { present the }\end{array}$ & $\begin{array}{l}\text { 4. Quest } \\
\text { ioning }\end{array}$ & $\begin{array}{l}\text { discuss } \\
\text { appropriate }\end{array}$ & \begin{tabular}{|l} 
The teacher \\
asks students to
\end{tabular} \\
\hline
\end{tabular}

\begin{tabular}{|c|c|c|c|}
\hline $\begin{array}{l}\text { result of } \\
\text { discussion } \\
\text { with groups. } \\
\text { The other } \\
\text { groups give a } \\
\text { coment. }\end{array}$ & $\begin{array}{l}\text { Students } \\
\text { to } \\
\text { generate } \\
\text { or create } \\
\text { any } \\
\text { question } \\
\text { s about } \\
\text { what } \\
\text { they } \\
\text { have } \\
\text { read. }\end{array}$ & $\begin{array}{l}\text { solutions to } \\
\text { the problems } \\
\text { that occur in } \\
\text { text with } \\
\text { group. } \\
\text { 5. Commun } \\
\text { icating } \\
\text { Question } \\
\text { The teacher } \\
\text { asks students } \\
\text { to generate } \\
\text { or create any } \\
\text { questions } \\
\text { about what } \\
\text { they have } \\
\text { read. } \\
\text { The teacher } \\
\text { asks students } \\
\text { to present } \\
\text { the results of } \\
\text { grouping and } \\
\text { conclusions } \\
\text { based on the } \\
\text { analysis of } \\
\text { written and } \\
\text { orraly }\end{array}$ & $\begin{array}{l}\text { present the } \\
\text { results of group } \\
\text { work based on } \\
\text { the analysis of } \\
\text { written and } \\
\text { orraly }\end{array}$ \\
\hline
\end{tabular}

\section{Conceptual Framework}

This framework is intended to express and show the perception of the relationship between the variables to be studied based on the formulation of the problem. The relationship between variables can be described as follows: Figure 1. Conceptual Framework

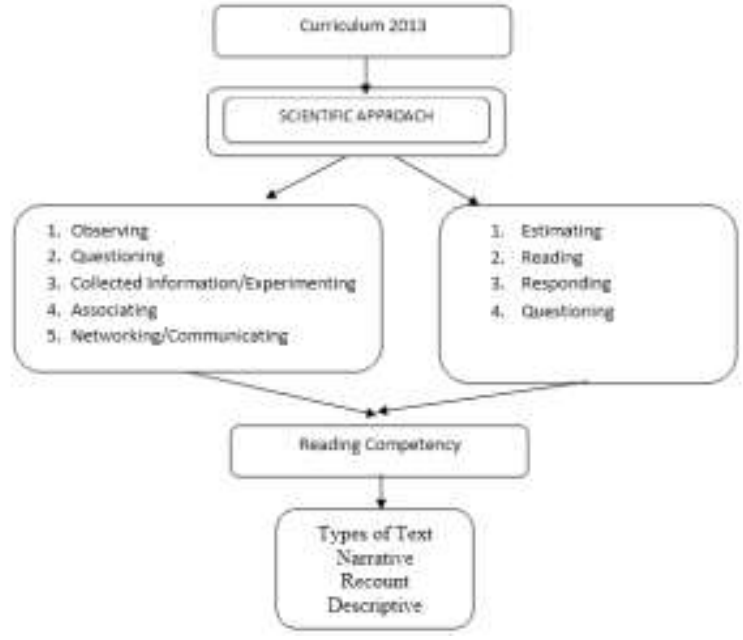

\section{Research Hypothesis}

The research hypothesis are:

1. There is a significant effect of scientific approach combined with ERRQ strategy on the eighth grade student's reading competency at SMP Santo Yoseph Denpasar. 
Statistically, it could be stated as follows:

2. There is no significant differences of the effect of scientific approach combined with ERRQ strategy viewed from text types namely; narrative, recount, descriptive on the eighth grade student's reading competency at SMP Santo Yoseph Denpasar.

Statistically, it could be stated as follows:

\section{RESEARCH METHODS}

In this research, research design is Quantitative research which was Experiment. Experimental design used a Posttest-Only Control Group Design. This design was chosen with a consideration that pretesting is not done to administer this research. There are three variables in this study; the first variable is the independent variable that is scientific approach combined with ERRQ strategy, the second variable is the moderator variables that is text types with three levels namely narrative, recount, descriptive text. And the third variable is the dependent variable that is reading competency.

\section{Population}

The research population consisted of all students of the eighth grade students of SMP Santo Yoseph Denpasar. They were distributed into eight classes. The distribution of students in each class can be seen in Table 2. below.

Table 2. Number of Students in Population

\begin{tabular}{|l|l|l|}
\hline No & CLASS & $\begin{array}{l}\text { NUMBER } \\
\text { STUDENTS }\end{array}$ \\
\hline 1 & VIII A & 41 \\
\hline 2 & VIII B & 39 \\
\hline 3 & VIII C & 40 \\
\hline 4 & VIII D & 36 \\
\hline 5 & VIII E & 40 \\
\hline 6 & VIII F & 36 \\
\hline 7 & VIII G & 40 \\
\hline 8 & VIII H & 40 \\
\hline \multicolumn{2}{|l|}{ TOTAL } & 312 \\
\hline
\end{tabular}

\section{Sample and Sampling}

The research sample recruited using a Random Sampling, the researcher selected two classes from eight classes as the experimental group and control group. The groups chosen were class VIIIB as experimental group and class VIIID as control group. They were 75 students altogether. The experimental group consisted 39 students, while control group consisted 36 students. The experimental group treated by using scientific approach combined with ERRQ strategy and control group treated by using scientific approach combined with conventional strategy. Based on selection using the lottery, VIIIB was given treatment using scientific approach combined with ERRQ strategy and VIIID was given treatment using scientific approach combined with conventional strategy.

After the sample was determined, the test of homogeneity of the classs by Levene statistic was done to ensure that all of the groups of the sample were homogenous to each other. The data that was used was the score of daily examination of the two classes given by the teacher. Then, one-way ANOVA was administered after analyzing homogeneity of the two classes to prove whether those two classes there was a significant effect or not. All calculation was done by applying SPSS 17 . The result of homogeneity testing showed that the significance value of the two classes was 0.007 . It was over the significant point in which was 0.05 . It could be concluded that the variances of the two samples were homogenous. The significant value shown in one-way ANOVA was 0.000 , which also exceeded the value of 0.05 . This result indicated that the samples of the study had equal ability. Thus, the samples in the groups were suitable of the research.

\section{RESEARCH RESULTS DISCUSSION}

AND

This research was conducted at SMP Santo Yoseph Denpasar and took the eighth grade students as the population. In order to answer the problem of the study and also to prove the hypothesis, an experimental and control study was administered. By design, there were two groups used as the samples of the study. Through random sampling with lottery system, it was determined that class VIII 
$\mathrm{B}$ and VIIID were chosen as the samples of the study. Then, lottery was administered to determine which class would be treated through scientific approach combined with ERRQ strategy and which class would be treated through by scientific approach combined with conventional strategy. The result of the lottery showed that class VIIIB was treated by scientific approach combined with ERRQ strategy and class VIII D was treated through scientific approach combined with conventional strategy. Each group consisted of 39 and 36 students. As in the present study, there were three types of text used during the teaching and learning process. Those are narrative, recount and descriptive text.

In line with the design of the present study, the process of data collection was carried out in a series of teaching learning process. There were two meetings of each text type and at the third meeting, the post-test was administered to samples under study. The posttest was in form of reading competency test in form of multiple choice which the samples were instructed to answer 15 questions based on the reading text. Before the test was administered after the treatment, the content validity and reliability of the test were measured. From the analysis using Gregory's formula, it was obtained that the content validity of the test was 0.86 , which means that the test had very high validity.

\section{Reading Competency of SA+ERRQ and SA+CS Groups}

The data in this study classified into two data. They were as the following: 1) data of the group taught by using scientific approach combined with ERRQ strategy, 2) data of the group taught by using scientific approach combined with conventional strategy. The data gathered were firstly analyzed descriptively in order to find reading competency of experimental and control groups. The descriptive data of students' score in reading competency was presented below.

Table 3. The Descriptive Data of Experimental and Control Groups

\begin{tabular}{|l|l|c|}
\hline Groups & Text & Descriptive Statistic \\
\cline { 3 - 3 } & Types & $\bar{X}$ \\
\hline & Narrative & $\mathbf{8 0 . 1 7}$ \\
\hline
\end{tabular}

\begin{tabular}{|l|l|l|}
\hline \multirow{3}{*}{$\begin{array}{l}\text { Experimental } \\
\text { Group }\end{array}$} & Recount & $\mathbf{8 0 . 1 7}$ \\
\cline { 2 - 3 } & $\begin{array}{l}\text { Descripti } \\
\text { ve }\end{array}$ & $\mathbf{8 0 . 3 4}$ \\
\cline { 2 - 3 } Control & Total & $\mathbf{8 0 . 2 2}$ \\
\hline \multirow{5}{*}{ Group } & Narrative & $\mathbf{7 2 . 7 7}$ \\
\cline { 2 - 3 } & Recount & $\mathbf{7 6 . 8 5}$ \\
\cline { 2 - 3 } & $\begin{array}{l}\text { Descripti } \\
\text { ve }\end{array}$ & $\mathbf{7 3 . 3 3}$ \\
\cline { 2 - 3 } & Total & $\mathbf{7 4 . 3 2}$ \\
\cline { 2 - 3 } & $\begin{array}{l}\text { Total } \\
\text { mean } \\
\text { score }\end{array}$ \\
\hline
\end{tabular}

Source: Data analysis SPSS 17 for Windows, April 2016

Based on the data displayed on table 4.3, it could be described that the mean scores of students which was treated through the application of experimental group in general was 80.22 whilst the general mean scores of students treated in control group was 74.32. Based on the text types used for each strategy, the result of the analysis showed that the mean score of experimental group using narrative text was 80.17 , the mean score of experimental group using recount text was 80.17 , the mean score of experimental group using descriptive text was 80.34. They were presented in accordance with the research problems of the present study: reading competency of scientific approach combined with ERRQ strategy. From the data above, the mean scores of experimental group higher than control group.

\section{Reading Competency of SA+ERRQ viewed from Text Types}

The data in this study classified into six data. They were as the following: 1) data of the group taught by using scientific approach combined with ERRQ strategy viewed narrative text, 2) data of the group taught by using scientific approach combined with ERRQ strategy viewed recount text, 3) data of the group taught by using scientific approach combined with ERRQ strategy viewed descriptive text, 4) data of the group taught by using scientific approach combined with conventional strategy viewed narrative text, 5) data of the group taught by using scientific approach combined with conventional strategy viewed recount text, 6) data of the group taught by using scientific approach combined with conventional strategy viewed descriptive text. The descriptive data of students' score in reading competency viewed from text types, the 
data can be classified that can be seen in the table below.

Table 4. The Descriptive Data of All Variables Under Study

\begin{tabular}{|l|l|l|l|l|}
\hline \multirow{2}{*}{ Groups } & Text Types & \multicolumn{3}{|c|}{ Descriptive Statistic } \\
\cline { 3 - 5 } & & $\bar{X}$ & \multicolumn{1}{|c|}{} & \multicolumn{1}{|c|}{} \\
\hline \multirow{3}{*}{$\begin{array}{l}\text { Experiment } \\
\text { al Group }\end{array}$} & Narrative & $\mathbf{8 0 . 1 7}$ & $\mathbf{9 . 9 6}$ & $\mathbf{9 9 . 3 8}$ \\
\cline { 2 - 5 } & Recount & $\mathbf{8 0 . 1 7}$ & $\mathbf{9 . 9 6}$ & $\mathbf{9 9 . 3 8}$ \\
\cline { 2 - 5 } & Descriptive & $\mathbf{8 0 . 3 4}$ & $\mathbf{9 . 1 7}$ & $\mathbf{8 4 . 0 9}$ \\
\cline { 2 - 5 } & Total & $\mathbf{8 0 . 2 2}$ & $\mathbf{5 . 7 8}$ & $\mathbf{3 3 . 4 7}$ \\
\hline \multirow{4}{*}{$\begin{array}{l}\text { Control } \\
\text { Group }\end{array}$} & aarrative & $\mathbf{7 2 . 7 7}$ & $\mathbf{9 . 3 4}$ & $\mathbf{8 7 . 3 0}$ \\
\cline { 2 - 5 } & Recount & $\mathbf{7 6 . 8 5}$ & $\mathbf{9 . 4 9}$ & $\mathbf{9 0 . 1 2}$ \\
\cline { 2 - 5 } & Descriptive & $\mathbf{7 3 . 3 3}$ & $\mathbf{9 . 9 5}$ & $\mathbf{9 9 . 0 4}$ \\
\cline { 2 - 5 } & Total & $\mathbf{7 4 . 3 2}$ & $\mathbf{7 . 0 9}$ & $\mathbf{5 0 . 3 4}$ \\
\hline
\end{tabular}

Source: Data analysis SPSS 17 for Windows, April 2016

Based on the data displayed on table 5, it could be described that the mean scores of students which was treated through the application of experimental group in general was 80.22 whilst the general mean scores of students treated in control group was 74.32. Based on the text types used for each strategy, the result of the analysis showed that the mean score of experimental group using narrative text was 80.17 , the mean score of experimental group using recount text was 80.17 , the mean score of experimental group using descriptive text was 80.34 .

The standard deviation of students in experimental group was 5.78, the standard deviation of students in control group was 7.09. The standard deviation of students in experimental group using narrative text was 9.96, the standard deviation of students in experimental group using recount text was 9.96, and the standard deviation of students in experimental group using descriptive text was 9.17. In control group, the standard deviation of the students control group using narrative text was 9.34, the standard deviation of students in control group using recount text was 9.49 and the standard deviation of students in control group using descriptive text was 9.95.

The variance of students in experimental group was 33.47 , the variance of students in control group was 50.34. The variance of students in experimental group using narrative text was 99.38, the variance of students in experimental group using recount text was 99.38, the variance of students in experimental group using descriptive text was 84.09. The variance of students in control group using narrative text was 87.30, the variance of students in control group using recount text was 90.12, the variance of students in control group using descriptive text was 99.04.

This study concerned on the result of analysis of the students' reading competency (post-test) score. They were presented in accordance with the research problems of the present study: reading competency of scientific approach combined with ERRQ strategy viewed narrative text, reading competency of scientific approach combined with ERRQ strategy viewed recount text and reading competency of scientific approach combined with ERRQ strategy viewed descriptive text. From the data above, there was no the differences of reading competency using text types between experimental and control group.

\section{Discussion}

As what has been mentioned previously that the present study was an experimental research aimed at finding out whether or not there is (1) the significant effect of scientific approach combined with ERRQ strategy on students' reading competency, (b) the significant differences of the effect of scientific approach combined with ERRQ strategy viewed from text types on students' reading competency. The data were collected by administering reading competency test at the end of the treatment in each group. The reading competency test was in form of multiple choice which consisted of 15 items for each text type. The data obtained from the result of post-test were analyzed descriptively and inferentially.

The first result of descriptive analysis that analyzed the students' reading competency in all of the three text types showed that the reading competency of the students in $\mathrm{SA}+\mathrm{ERRQ}$ group was higher than those in $\mathrm{SA}+\mathrm{CS}$ group. This fact can be seen from the grand mean score of both groups. The grand mean scores of the group which was taught with SA+ERRQ was 80.22 , while the grand mean score of group which was taught with SA+CS was 74.32. It means that the grand mean scores of SA+ERRQ group was higher than SA+CS 
group by 5.90 points. This descriptive analysis clearly pointed out that the students who were treated through the implementation of SA+ERRQ performed better than those who were treated through the implementation of $\mathrm{SA}+\mathrm{CS}$.

The result of inferential analysis by using statistical one-way ANOVA which was applied in the present study for the first hypothesis showed that the significant value was 0.001 . This figure was clearly less than the significant value 0.05 . It means that statically, there was significant effect of scientific approach combined with ERRQ strategy on students' reading competency. Thus, therefore the directional hypothesis which stated that the effect of SA+ERRQ is more significant than the effect of SA+CS was accepted. This finding indicated that the treatment by implementing SA+ERRQ and SA+CS in teaching reading competency yielded the different significant result. In other words, both of the strategies had not equal effect on reading competency of the eighth grade students of SMP Santo Yoseph Denpasar.

The second research question was about the differences of the effect of scientific approach combined with ERRQ strategy viewed from text types (narrative, recount and descriptive) on reading competency. The result of descriptive analysis obviously showed there were different achievements among the different text types. The mean score of the samples for the narrative and recount text was 80.17. In addition, the mean score of descriptive text was higher than the mean score of narrative and recount text by 0.17 points, that was 80.34 . Further, the inferential analysis which was done by applying one-way ANOVA showed that the significant value was 0.145 . This figure was above the significant value 0.05 . It means that there were no statiscally significant differences of the effect of SA+ERRQ on students' reading competency viewed text types. From this result, it can be concluded that the result of the treatment by implementing SA+ERRQ in reading on the three text types yielded the same result. It means that SA+ERRQ applicably worked during the learning process of reading on those three text types.

Basically, the teaching-learning atmosphere in SMP Santo Yoseph Denpasar has been running well. Moreover, the enthusiasts of the eighth grade students at SMP Santo Yoseph Denpasar in following English subject are very high that could help the students easier to understand some types of text. Furthermore, English teacher has applied type of reading texts in improving students reading competency. According to English teacher, each individual of the students has the equal concept in understanding certain types of English texts. This equivalent understanding supports each student to be a good competitor in learning English particularly in the area of reading skill.

From the discussion above it can be concluded that reading competency and teaching strategy are closely associated to each other. Reading competency is the ability in mastering idea and content of the reading passage through analyzing, evaluating and combining the ideas with the prior knowledge. To maintain a student to be creative and enjoy to read, neither scientific approach combined with ERRQ strategy empowers them to be competence readers.

\section{Conclusion}

The findings of the present experimental study finally revealed the research problems which have already been previously formulated. Firstly, there was statistically significant effect of scientific approach combined with ERRQ strategy on students' reading competency. However, the group that studied by using scientific approach combined with ERRQ strategy surpassed the group that studied using scientific approach combined with conventional strategy where the result of descriptive analysis shows that the mean scores of SA+ERRQ group students was higher than the mean scores of SA+CS group students. Secondly, there was no statistically significant differences of the effect of scientific approach combined with ERRQ strategy viewed text types on students' reading competency. 
Based on the research finding discusses, the conclusion of this study can be elaborated as follows. The result of inferential analysis showed that there was significant effect of scientific approach combined with ERRQ strategy on the eighth grade students' reading competency at SMP Santo Yoseph Denpasar. The result of inferential analysis showed that there were no significant differences of the effect of scientific approach combined with ERRQ strategy viewed from text types on the eighth grade students' reading competency at SMP Santo Yoseph Denpasar.

\section{REFERENCES}

[1] Anchin, David.(1995).Learning strategies resources guide. Florida: Litton/PRC,inc.

[2] Bayu, W. 2008. Improving the students' ability in reading comprehension through jigsaw technique. A classroom action based research conducted at SMA Negeri 3 Singaraja in the academic year 2008/2009. Unpublished Thesis. IKIP N Singaraja.

[3] Brown, D.H. (2001). Teaching by principles: an interactive approach to language pedagogy. San Fransisco: Addison Wesley Longman, Inc

[4] Erawati. (2012). A comparative effect of metacognitive self-monitoring strategies on students' reading competency based on text types. Unpublished Magister Thesis. Singaraja: Ganesha University Press.

[5] Grabe, W. and Stoller, F.L. (2002). Teaching and researching reading. London: Longman.

[6] Iswara, Windansari. (2013). The effect of ERRQ strategy in teaching reading at baturraden. University: Yogyakarta.

[7] Kemdikbud. (2013). Pedoman pelatihan implementasi kurikulum 2013. Badan pengembangan sumber daya manusia pendidikan dan kebudayaan dan penjaminan mutu pendidikan.

[8] Kemdikbud. (2013). Materi pelatihan guru implementasi kurikulum 2013. Jakarta: Depdikbud

[9] Richards, J. C. and Schmidts, R. (2002). Longman dictionary of language teaching and applied linguistics. 3rd ed. London: Pearson Education Limited.

[10] Smith, T. et. al.(2012. (6th ed.). Teaching students with special needs in inclusive settings. Wesminster Hall: Upper Saddle River, NJ

[11] Winch, G. et.al. (2006). Literacy reading, writing and children literature. Third Edition. Oxford 